\title{
House dust mite allergen level and allergen sensitization as risk factors for asthma among student in Central Jakarta
}

Heru Sundaru

\begin{abstract}
Abstrak
Penelitian ini adalah penelitian berbasis komunitas untuk memperoleh gambaran kadar alergen tungau debu rumah (TDR) dan sensitisasi alergen sebagai faktor risiko asma. Penelitian ini merupakan studi potong lintang dengan responden 3.840 pelajar sekolah menengah pertama dari 19 sekolah yang dipilih secara acak dari 131 sekolah di Jakarta Pusat. Semua responden mengisi kuesioner International Study on Asthma and Allergy in Children (ISAAC). Dari 3.840 responden, 288 (7,5\%) digolongkan dalam kelompok asma karena mempunyai riwayat mengi selama 12 bulan terakhir. Pada kelompok asma, 207 responden melakukan uji kulit dan 135 diambil sampel debu rumah. Dari 2.601 responden yang tidak memiliki riwayat asma atau atopi lain, dipilih secara acak 274 orang untuk uji kulit dan 165 di antaranya diambil sampel debu rumah. Kadar alergen TDR tidak berbeda bermakna antara kelompok asma maupun non-asma baik untuk Der p1, Der f1, maupun Grup I. Risiko asma terutama disebabkan oleh sensitisasi alergen TDR D.pteronyssinuss (rasio odds (OR):12,68, interval kepercayaan (CI): 7,50-21,44), D.farinae (OR: 10,50, CI: 6,35-17,34), serta kecoak (OR:5,57, CI:3,44-9,01). Perbedaan risiko asma tidak berhubungan dengan tinggi rendahnya kadar alergen TDR tetapi oleh sensitisasinya. Kesimpulannya, sensitisasi alergen TDR dan kecoak perlu diperhatikan dalam upaya menurunkan risiko dan prevalensi asma. (Med J Indones 2006; 15:55-9)
\end{abstract}

\begin{abstract}
This study is a community-based study to get an overview about House Dust Mite (HDM) allergen level, allergen sensitization as risk factors of asthma. This is a cross-sectional study on 3,840 students from 19 junior high schools, aged 13-14 years. All of the respondents filled out the International Study on Asthma and Allergy in Children (ISAAC) questionnaire. Of 3840 respondents, 288 $(7.5 \%)$ were assigned to asthma group (experience wheezing during the last 12 months). The skin prick test was performed on 207 respondents and the house dust mite was collected from 135 respondents. Of 2601 respondents in non-asthma group, the skin prick test was randomly performed on 274 respondents and the house dust mite was collected from 165 respondents. There is no significant difference on HDM allergen concentration for Der p1, Der f1 or Group I between asthma and control group. The risk of asthma was caused especially by sen D.pteronyssinus (crude odds ration (OR): 12.68, 95\% confidence interval (CI): 7.50-21.44), D.farinae (OR: 10.50, CI: 6.35-17.34) and cockroach allergen (OR:5.57, CI:3.44-9.01). The risk for asthma was not correlated with the level of house dust mite allergens but its sensitization. In conclusion, sensitization to HDM and cockroach allergen should be concerned in order to reduce risk and prevalence of asthma. (Med J Indones 2006; 15:55-9)
\end{abstract}

Keywords: house dust mite, allergen sensitization, asthma, risk factor

Asthma is a common disease in children. The asthma prevalence in Indonesia is between 3-16\%, depends on the criteria diagnosis. ${ }^{1}$ The asthma problem is not related to the prevalence only. Asthma also reduced quality of life, increased the frequency of hospitalization, and asthma-related death. ${ }^{2,3,4}$ Based of these facts, the

Division of Allergy and Clinical Immunology, Department of Internal Medicine, Faculty of Medicine University of Indonesial Dr. Cipto Mangunkusumo Hospital, Jakarta, Indonesia study to find the etiology of asthma is important in order to reduce the prevalence and to manage the other problems related to asthma.

The etiology of asthma is still unclear. Most studies on asthma found that there is an interaction between genetic and environmental factors. ${ }^{5}$ The genetic factors have important role in development of asthma, but it fails to explain the increasing prevalence of asthma in very short period. It is proved by studies conducted on people of the same race living in different areas or countries that has different prevalence of asthma. This finding support the theory that environmental factors 
plays an important role in the mechanism of asthma as reported by von Mutius et $\mathrm{al}^{6}$ and Leung et $\mathrm{al}^{7}$. The environmental factors that have important role on the incidence of asthma are allergen sensitization ${ }^{8,9}$ and house dust mite (HDM) allergen. ${ }^{10}$

In Indonesia, most allergen sensitization relatedasthma studies are hospital-based. ${ }^{11}$ This situation is similar with HDM allergen level study. The objective of this study is to get an overview about HDM allergen level, allergen sensitization and risk of asthma related with them in the community based, especially among students.

\section{METHODS}

This study is a cross-sectional study on junior high school students in Central Jakarta, aged 13-14 years in 2004, who fulfilled the eligible criteria. Out of 131 junior high schools in Central Jakarta, 19 schools were randomly selected to be included into this study. All of the students filled out the ISAAC questionnaire that has been translated to Indonesian. We analyzed the group of students with asthma (experience wheezing during the last 12 months) and non-asthma (no history of wheezing, rhinitis or eczema).

\section{Skin Prick Test}

This test is performed for 6 type of allergens (Stallergen, Paris, France), positive control (temoin) and negative control (histamine). The type allergen are Dermatophagoides (D.) pteronyssinus, D. farinae, the cat epithel, the dog epithel, cockroach, Candida (C.) albicans and two controls i.e. temoin (negatif control) and histamine (positive control). Interpretation of skin test result according the Bousquet et.al ${ }^{12}$ :

- (negative) : equal to negative control or no wheal

$+\quad(+1)$ : diameter of wheal is $25 \%$ of positive control

$++(+2)$ : diameter of wheal is $50 \%$ of positive control

$++(+3)$ : diameter of wheal is $100 \%$ of positive control (the same with positive control)

$+++(+4)$ : diameter of wheal is larger than positive control

Skin prick test is reported as positive result if wheal size is +2 or more. The respondent was considered atopic if one or more skin prick tests were positive.

\section{House Dust}

Dust samples were collected from respondent's beds at their house. The top surface of beds was vacuumed on an area approximately one $\mathrm{m}^{2}$ for 3 minutes with vacuum cleaner (Fucuda, ZB300-258) whose inlet was installed with a filter which collected the dust. The filter with dust sample was stored in separated mini-grip plastic bags, sealed, and stored at refrigerator until analysis.

\section{House Dust Mite Analysis}

The measurement of HDM level was analyzed by ELISA, in collaboration with Department of Parasitology, Siriraj Hospital, Bangkok. The type of HDM allergens were Der p1, Der f1 and Group I (combination of Der $\mathrm{p} 1$ and $\mathrm{f1}$ ), which is reported as $\mu \mathrm{g}$ of HDM /gram of dust. The cut-off point was $2 \mu \mathrm{g} / \mathrm{g}$ dust, because the concentration of HDM greater than $2 \mu \mathrm{g} / \mathrm{g}$ dust was predicted will increasing the risk of sensitization.

\section{Ethical Clearance}

The study was approved by the Institutional Review Board of University of Indonesia, School of Medicine.

\section{Statistical Analysis}

Statistical analysis was done using Stata version 7.0. House dust mite level was analyzed with student ttest. Odds ratios (OR) of asthma according to HDM allergen level and allergen sensitization were estimated by the method of maximum likelihood, and their confident interval (CI) was based on exact method.

\section{RESULTS}

Of 3,840 respondents, $288(7.5 \%)$ were assigned to asthma group (experience wheezing during the last 12 months). The skin prick test was performed on 207 respondents in asthma group. Of 207 respondents, the house dust mite was collected from 135 respondents. The respondents who have no history of wheezing, allergic rhinitis and atopic dermatitis were assigned to control group. Of 2,601 respondents in control group, the skin prick test was randomly performed on 274 respondents, and the house dust mite was collected from 165 respondents among them. 
Table 1. Comparison of Der pl, Der fl and Group I allergen concentration (asthma v/s control)

\begin{tabular}{|c|c|c|c|}
\hline \multirow{2}{*}{$\begin{array}{l}\text { HDM } \\
\text { Allergens } \\
\text { Type }\end{array}$} & \multicolumn{2}{|c|}{ 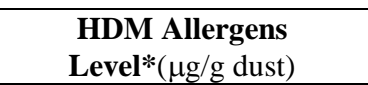 } & \multirow[t]{2}{*}{$p$ value } \\
\hline & $\begin{array}{l}\text { Control } \\
(n=164)\end{array}$ & $\begin{array}{l}\text { Asthma } \\
(\mathrm{n}=135)\end{array}$ & \\
\hline Derpl & $\begin{array}{c}0.28 \\
(0.23 ; 0.35) \\
\end{array}$ & $\begin{array}{c}0,29 \\
(0.23 ; 0.35) \\
\end{array}$ & 0.9501 \\
\hline $\operatorname{Der} f 1$ & $\begin{array}{c}1.28 \\
(1.07 ; 1.53)\end{array}$ & $\begin{array}{c}1.49 \\
(1.24 ; 1.80)\end{array}$ & 0.2371 \\
\hline Group I & $\begin{array}{c}1.85 \\
(1.58 ; 2.16) \\
\end{array}$ & $\begin{array}{c}2.08 \\
(1.78 ; 2.42) \\
\end{array}$ & 0.3021 \\
\hline
\end{tabular}

Table 1 showed there is no significant difference on house dust mite allergen concentration for Der pl, Der fl or Group I between asthma and control group. The concentration of Derfl is higher than Der pl.

Table 2. Proportion distribution and OR of asthma according to HDM allergen level

\begin{tabular}{|c|c|c|c|c|}
\hline \multirow{2}{*}{$\begin{array}{l}\text { HDM } \\
\text { Allergens } \\
\text { Level }\end{array}$} & $\begin{array}{l}\text { Control } \\
(\mathrm{N}=164) \\
\end{array}$ & $\begin{array}{l}\text { Asthma } \\
(\mathrm{N}=135) \\
\end{array}$ & \multirow{2}{*}{$\begin{array}{c}\text { Crude OR } \\
(95 \% \mathrm{CI})\end{array}$} & \multirow{2}{*}{ p value } \\
\hline & n (\%) & n (\%) & & \\
\hline \multicolumn{5}{|l|}{$\begin{array}{l}\text { Der pl } \\
(\mu \mathrm{g} / \mathrm{g} \text { dust })\end{array}$} \\
\hline$<2$ & $\begin{array}{c}155 \\
(94.51)\end{array}$ & $\begin{array}{c}130 \\
(96.30)\end{array}$ & 1 & \\
\hline$\geq 2$ & $\begin{array}{c}9 \\
(5.49) \\
\end{array}$ & $\begin{array}{c}5 \\
(3.70) \\
\end{array}$ & $\begin{array}{c}0.66 \\
(0.22 ; 2.03) \\
\end{array}$ & 0.4682 \\
\hline \multicolumn{5}{|l|}{$\begin{array}{l}\text { Derfl } \\
\text { ( } \mu \mathrm{g} / \mathrm{g} \text { dust) }\end{array}$} \\
\hline$<2$ & $\begin{array}{c}107 \\
(65.24)\end{array}$ & $\begin{array}{c}89 \\
(65.93)\end{array}$ & 1 & \\
\hline$\geq 2$ & $\begin{array}{c}57 \\
(34.76) \\
\end{array}$ & $\begin{array}{c}46 \\
(34.07) \\
\end{array}$ & $\begin{array}{c}0.97 \\
(0.60 ; 1.57)\end{array}$ & 0.9019 \\
\hline \multicolumn{5}{|l|}{$\begin{array}{l}\text { Group 1 } \\
\text { ( } \mu \mathrm{g} / \mathrm{g} \text { dust) }\end{array}$} \\
\hline$<2$ & $\begin{array}{c}80 \\
(48.78)\end{array}$ & $\begin{array}{c}74 \\
(54.81)\end{array}$ & 1 & \\
\hline$\geq 2$ & $\begin{array}{c}84 \\
(51.22) \\
\end{array}$ & $\begin{array}{c}61 \\
(45.19) \\
\end{array}$ & $\begin{array}{c}0.79 \\
(0.05 ; 1.24)\end{array}$ & 0.2996 \\
\hline
\end{tabular}

HDM level greater than $2 \mu \mathrm{g} / \mathrm{g}$ dust is more frequent on Der $\mathrm{f} 1$ than Der p1 allergen. There is no significant difference on Der f1, Der p1, or Group I allergens between the subgroup of allergen level $<2 \mu \mathrm{g} / \mathrm{g}$ dust and $\geq 2 \mu \mathrm{g} / \mathrm{g}$ dust, both in asthma and control group.

Table 3 showed the comparison of the results of skin prick test for 6 allergens. The highest frequency of sensitization is sensitization to D. pteronyssinus and
D. farinae, followed by cockroach, the cat epithel and C.albicans.

Table 3. Proportion distribution and OR of asthma according to allergen sensitization

\begin{tabular}{|c|c|c|c|c|}
\hline Sensitization & $\begin{array}{c}\begin{array}{c}\text { Control } \\
(\mathrm{N}=274)\end{array} \\
(\%)\end{array}$ & $\begin{array}{c}\begin{array}{c}\text { Asthma } \\
(\mathrm{N}=207)\end{array} \\
(\%)\end{array}$ & $\begin{array}{r}\text { Crude OR } \\
(\mathbf{9 5 \%} \mathbf{C I})\end{array}$ & $\mathbf{p}$ \\
\hline \multicolumn{5}{|l|}{ D. pteronyssinus } \\
\hline- & $\begin{array}{c}216 \\
(78.83)\end{array}$ & $\begin{array}{c}47 \\
(22.71)\end{array}$ & 1 & \\
\hline+ & $\begin{array}{c}58 \\
(21.17)\end{array}$ & $\begin{array}{c}160 \\
(77.29)\end{array}$ & $\begin{array}{c}12.68 \\
(7.50 ; 21.44)\end{array}$ & 0.0000 \\
\hline \multicolumn{5}{|l|}{$D$ farinae } \\
\hline- & $\begin{array}{c}225 \\
(82.12)\end{array}$ & $\begin{array}{c}63 \\
(30.43)\end{array}$ & 1 & \\
\hline+ & $\begin{array}{c}49 \\
(17.88) \\
\end{array}$ & $\begin{array}{c}144 \\
(69.57) \\
\end{array}$ & $\begin{array}{c}10.50 \\
(6.35 ; 17.34)\end{array}$ & 0.0000 \\
\hline \multicolumn{5}{|l|}{ Cockroach } \\
\hline- & $\begin{array}{c}239 \\
(87.23)\end{array}$ & $\begin{array}{c}114 \\
(55.07)\end{array}$ & 1 & \\
\hline+ & $\begin{array}{c}35 \\
(12.77) \\
\end{array}$ & $\begin{array}{c}93 \\
(44.93) \\
\end{array}$ & $\begin{array}{c}5.57 \\
(3.44 ; 9.01) \\
\end{array}$ & 0.0000 \\
\hline \multicolumn{5}{|l|}{ Dog } \\
\hline- & $\begin{array}{c}259 \\
(94.53)\end{array}$ & $\begin{array}{c}199 \\
(96.14)\end{array}$ & 1 & \\
\hline+ & $\begin{array}{c}15 \\
(5.47)\end{array}$ & $\begin{array}{c}8 \\
(3.86)\end{array}$ & $\begin{array}{c}0.69 \\
(0.29 ; 1.67)\end{array}$ & 0.4132 \\
\hline \multicolumn{5}{|l|}{ Cat } \\
\hline- & $\begin{array}{c}266 \\
(97.08)\end{array}$ & $\begin{array}{c}193 \\
(93.24)\end{array}$ & 1 & \\
\hline+ & $\begin{array}{c}8 \\
(2.92) \\
\end{array}$ & $\begin{array}{c}14 \\
(6.76) \\
\end{array}$ & $\begin{array}{c}2.41 \\
(0.99 ; 6.56)\end{array}$ & 0.0460 \\
\hline \multicolumn{5}{|l|}{ C.albicans } \\
\hline- & $\begin{array}{c}267 \\
(97.45)\end{array}$ & $\begin{array}{c}194 \\
(93.72)\end{array}$ & 1 & \\
\hline+ & $\begin{array}{c}7 \\
(2.55) \\
\end{array}$ & $\begin{array}{c}13 \\
(6.28) \\
\end{array}$ & $\begin{array}{c}2.56 \\
(1.00 ; 6.56) \\
\end{array}$ & 0.0429 \\
\hline \multicolumn{5}{|l|}{ Atopy } \\
\hline - & $\begin{array}{c}209 \\
(76.28)\end{array}$ & $\begin{array}{c}43 \\
(20.77)\end{array}$ & 1 & \\
\hline+ & $\begin{array}{c}65 \\
(23.72)\end{array}$ & $\begin{array}{c}164 \\
(79.23)\end{array}$ & $\begin{array}{c}12.26 \\
(7.27 ; 20.69)\end{array}$ & 0.0000 \\
\hline
\end{tabular}

Mainly D.pteronyssinus and D. farinae allergen caused the risk for asthma. The non-significant difference between asthma and control group was only found on the dog epithel allergen.

\section{DISCUSSION}

The mean allergen level of Der p1 $(0.29 \mu \mathrm{g} / \mathrm{g}$ dust $)$ or Der f1 $(1.49 \mu \mathrm{g} / \mathrm{g}$ dust) is relatively low than the developed countries whose asthma prevalence is high. Australia reported the Der p1 allergen level between $6.50-47.80 \mu \mathrm{g} / \mathrm{g} .{ }^{8}$ New Zealand reported the mean Der $\mathrm{p} 1$ level is greater than $10 \mu \mathrm{g} / \mathrm{g} .{ }^{10}$ 
International conference on HDM stated that there is correlation between the concentrations of HDM/gram of dust with HDM allergen level. ${ }^{13}$ Based of this assumption, the concentration of HDM/gram of dust in Central Jakarta is also low. The environmental condition of Indonesia supported the HDM living because of its humidity and temperature. ${ }^{14}$ The relatively low of allergens or HDM level is probably caused by different life style, where in the developed countries there are four seasons, using carpet for the floor, and the room is always closed during the winter. This situation caused the HDM can bread well.

This study shows no different allergen Der $\mathrm{p} 1$ and Der f1 concentration between asthma and non-asthma group. It is shown that the incidence of asthma is not only determined by HDM allergens only, but there are another factors such as history of asthma in the family, another allergen or idiopathic factors. ${ }^{15}$

The degree of allergen concentration (Table 2), did not influence the risk of asthma episode, although Dowse et $\mathrm{al}^{16}$ found that the high prevalence of asthma is correlated with high concentration of HDM allergen. Anto ${ }^{17}$ proposed a hypothesis that worsening of asthma episode can caused by exposure of the allergen; the incidence of asthma not directly correlated with the allergen concentration, but through allergen sensitization. Correlation between degree of asthma prevalence and concentration of HDM allergen still a contradiction. Wicken et $\mathrm{al}^{10}$ found that high concentration of HDM allergen is common in developed countries, this finding is correlate with high incidence of asthma in that countries, but this findings is different with Pearce et al. ${ }^{18}$ They found that high prevalence of asthma did not correlated with allergen concentration.

This study found different result compared with International Conference that is stated that HDM allergen $\geq 2 \mu \mathrm{g} / \mathrm{g}$ is a risk factor for sensitization and incidence of asthma. Concentration of Der pl 0.29 $\mu \mathrm{g} / \mathrm{g}$ dust is given a positive reaction $77 \%$ in asthma group (Table 2), $96.3 \%$ of asthma group have concentration of Der $p 1<2 \mu \mathrm{g} / \mathrm{g}$ dust. The consensus of cut-off point for allergen concentration $2 \mu \mathrm{g} / \mathrm{g}$ dust is compiled from the places which have relatively high allergen level. Therefore, it is possible that the lower allergen concentration will give positive reaction in this study. Munir et $\mathrm{al}^{19}$ reported that the lower allergen concentration could inducing sensitization, mainly in people with family history of allergy.
Allergen sensitization is one of risk factor that has important role in asthma. Sears et $\mathrm{al}^{20}$ reported that sensitization with HDM, cat epithel, dog epithel, and fungus spore allergens was correlated with the increasing risk of asthma. Duffy et $\mathrm{al}^{21}$ reported the correlation of mean wheal size in skin prick test using HDM allergens with the frequency of wheezing and bronchus hyperresponsiveness. This study found that D.pteronyssinus allergen is the most frequent allergen inducing sensitization in asthma patients (Table 3). In atopic group, $94.69 \%$ sensitization is induced by D.pteronyssinus. Therefore, it can be stated that atopic status in children can be determined with this allergen.

The other allergen, such as D.farinae, also induced sensitization among $69.57 \%$ respondents in asthma group. There is cross reaction between sensitization to D.pteronyssinus and D.farinae allergens. ${ }^{22}$ This study also found a co-linearity between sensitization to D.pteronyssinus and D.farinae as $82.9 \%$. Therefore, in daily practice, allergen sensitization to D.pteronyssinus represented both allergens.

The role of allergen sensitization to the prevalence of asthma also reported by studies that was conducted in separated countries. ${ }^{9,23}$ In general, there was significant correlation between sensitization to HDM allergens and the prevalence of asthma in each country.

From another studies that was conducted at slum areas, Rosentreich et $\mathrm{al}^{24}$ found that cockroach allergen could induced sensitization. Our study found that $44.93 \%$ respondents of asthma group showed positive reaction to cockroach allergen. Cockroach allergen can induced severe asthma which can disturbed daily activities and increased the patient's admission to emergency room or hospitalization. ${ }^{24}$

The cat epithel is strong allergen, but our study found that only $6.76 \%$ respondents in asthma group showed positive reaction. Meanwhile, sensitization to the dog allergen is lower $(3.86 \%)$ than cat allergen. This finding is different strickly with the results of studies in US. ${ }^{25}$ Most of houses (30-50\%) in these countries have dog or cat as pet. Indonesian people who take care dog or cat is rare, so, the level of sensitization to these pets is low.

\section{CONCLUSION}

HDM allergens can induced sensitization among $77 \%$ respondents in asthma group. The most frequent 
allergens inducing sensitization are house dust mite and cockroach. Therefore, these allergens should be concerned on the effort to reduce the risk or prevalence of asthma.

\section{Acknowledgments}

The author thanks to Sukamto, MD, internist, Ambara Baratawidjaja-Velasco,MD, Carolina SKM, Dewina Meutia Ramli Ssi, Widiarti Ariani SKM, Chairul Imam Darna SKM, Nia AMK, Oktriyani Ssi, Apt, Yudi Ferdian SE, Fahmi, and special thanks to Nat Malainual PhD, Assistant Professor of Department of Parasitology Faculty of Medicine Siriraj Hospital, Bangkok.

\section{REFERENCES}

1. Matondang CS. Asthma in children: view point from Indonesia. Med J Indones 1994;3:25-9.

2. Sundaru H. Perbandingan prevalensi dan derajat berat asma antara daerah urban dan rural pada siswa sekolah usia 13-14 tahun. Disertasi. Universitas Indonesia. 2005.

3. Lai CKW, de Guia TS, Kim YY, Kuo SH, Mukhopadhyay A, Soriano JB, et al. Asthma control in the Asia Pacific region, the Asthma Insights and Reality in Asia Pacific Study. J Allergy Clin Immunol 2003;111:263-8.

4. Vollmer WM, Osborne ML, Buist AS. 20 years trends in the prevalence of asthma and chronic airflow obstruction in an HMO. Am J Respir Crit Care Med 1998;157:1079-84.

5. Jackson R, Sears MR, Beaglchose R, Rea HH. International trends in asthma mortality. 1970-1985. Chest 1988;94:914-9.

6. Von Mutius E. Influences in allergy: epidemiology and the environment, J Allergy Clin Immunol 2004;113:373-9.

7. Cookson W. The alliance of genes and environment in asthma and allergy. Nature 1999;402 (suppl):B5-11.

8. Von Mutius E, Martinez F, Fritzsch C, Nicolai T, Roell G, Thiemman H. Prevalence of asthma and atopy in two areas of West and East Germany. Am J Respir Crit Care Med 1994;149:358-64.

9. Leung R, HO P. Asthma, allergy and atopy in three South East Asian populations. Thorax 1994;49:1205-10.

10. Peat JK, Tovey E, Toelle BG, Habby MM, Grey EJ, Mahmic A, et al. House dust mite allergens: a major risk factor for childhood asthma in Australia. Am J Respir Crit Care Med 1996;153;141-6.

11. Wickens $\mathrm{K}$, de Bruyne J, Calvo M, Choon-Kook S, Jayoraj G, Lai CKW, et al. The determinant of dust mite alergens and its relationship to the prevalence of symptoms of asthma in the Asia-Pacific region. Pediatr Allergy Immunol 2004;15:55-61.

12. Bousquet J, Michel FJ. In vivo methods for study of allergy: skin tests, techniques and interpretation. In:
Middleton, Reed CE, Ellis FF, Adkinson NF, Yunginger JW, Busse WW. Allergy principles and practise, $4^{\text {th }}$ ed. St-Louis: Mosby-Year Book. Inc; 1993. p.573-94.

13. Luczynka CM, Arruda LK, Platt Mills TAE, A two site monoclonal antibody Elisa for the major Dermatophagoides spp allergens der $\mathrm{p} 1$ and der f1. J Immunol Method 1989; 118:227-35.

14. Platts-Mills TAE, Thomas WR, Aeberse RC, et al. Dust mite allergens and asthma: Report of a second international workshop. J Allergy Clin Immunol 1992;89:1045-60.

15. Collof MJ. The effect of temperature and relative humidity on development times and mortality eggs from laboratory and wild populations of European house dust mite Dermatophagoides pteronyssinus (Acar: Pyroglyphidae). Exp Appl Acarol 1987;3:279-89.

16. National Insitute of Health Publication number 95-5659. Global Initiative for Asthma: Global strategy for asthma management and prevention NHLBI/WHO workshop report. Revised 2002. Maryland: National Institute of Health;2002.

17. Dowse GK, Turner KJ, Stewart GA, Alpers MP, Wooclock AJ. The association between Dermatophagoides mites and the increasing prevalence of asthma in villages communicaties within the Papua New Guinea highland. J Allergy Clin Immunol 1985;75:75-83.

18. Anto JM. The causes of asthma: the need to look at the data with different eyes. Allergy 2004;59:121-3.

19. Pearce N, Douwes J, Beasley R. Is allergen exposure the major primary cause of asthma?. Thorax 2000;55:424-31.

20. Munir AKM, Kjellman M, Bjorksten B. Exposure to indoor allergens in early infancy and sensitization. $\mathrm{J}$ Allergy Clin Immunol 1997;100:177-81.

21. Sears MR, Herbison GP, Holdaway MD, Hewitt CJ, Flannery EM, Silva PA. The relative risk of sensitivity to gross pollen, house dust mite and cat dander in the development of childhood asthma. Clin Exp Allergy 1989;19:419-24.

22. Sidenius KE, Hallas TE, Poulsen LK, Mosbech H. Allergen cross-reactivity between house-dust mites and other invertebrates. Allergy 2001;56:723-733.

23. Squillace SP, Sporik RB, Raxes G, Couture N, Lawrence A, Merriem S, et al. Sensitization to dust mites a dominant risk factor for asthma among adolesants living in Central Virginia. Multiple regression analysis of a population study. Am J Respir Crit Care Med 1997;150:1760-4.

24. Rosenstreich DL, Eggleston P, Kattan M, Baker D, Slavin RG, Gergen P, et al. The role of cockroach allergy and exposure to cockroach allergen in causing morbidity among inner-city children with asthma. N Engl J Med 1997;336:1356-63.

25. Patchett K, Lewis S, Crane J, Fitzharris P. Cat allergen (Fel d1) levels on school children's clothing and in primary school classroom in Wellington New Zealand. J Allergy Clin Immunol 1997;100:755-9. 